Article

\title{
Amendment of Husk Biochar on Accumulation and Chemical Form of Cadmium in Lettuce and Pak-Choi Grown in Contaminated Soil
}

\author{
Kuei-San Chen ${ }^{1}$, Chun-Yu Pai ${ }^{2}$ and Hung-Yu Lai ${ }^{1,3, *(D)}$ \\ 1 Department of Soil and Environmental Sciences, National Chung Hsing University, Taichung 40227, Taiwan; \\ s104039023@smail.nchu.edu.tw \\ 2 Department of Agronomy, National Taiwan University, Taipei 10617, Taiwan; r08628311@ntu.edu.tw \\ 3 Innovation and Development Center of Sustainable Agriculture, National Chung Hsing University, \\ Taichung 40227, Taiwan \\ * Correspondence: soil.lai@nchu.edu.tw; Tel.: +886-422-840-373
}

Received: 11 February 2020; Accepted: 18 March 2020; Published: 20 March 2020

\begin{abstract}
Background: Cadmium (Cd) accumulated in vegetables not only affects their growth but can also enter the human body via food chains and lead to various illnesses. Plants can decrease the toxicity by changing the chemical forms of $\mathrm{Cd}$, which include inorganic $\left(\mathrm{F}_{\mathrm{E}}\right)$, water-soluble $\left(\mathrm{F}_{\mathrm{W}}\right)$, pectate- and protein-integrated $\left(\mathrm{F}_{\mathrm{NaCl}}\right)$, undissolved phosphate $\left(\mathrm{F}_{\mathrm{HAc}}\right)$, oxalate $\left(\mathrm{F}_{\mathrm{HCl}}\right)$, and residual forms $\left(F_{R}\right)$. Among them, $F_{E}$ and $F_{W}$ chemical forms show higher mobility to translocate upward from roots to shoots compared with the others. (2) Methods: Different varieties or cultivars of lettuce and pak-choi were grown in Cd-contaminated soils amended with husk biochar (BC) to replenish nitrogen to the recommended amount and also to raise the soil $\mathrm{pH}$ value. (3) Results: More than $73 \%$ of the accumulated $\mathrm{Cd}$ in the edible organs was compartmentalized in $\mathrm{F}_{\mathrm{E}}$ chemical form in both leafy vegetables regardless of treatments. In comparison with control, the application of BC decreased the $\mathrm{Cd}$ concentrations and bioconcentration factors in the roots and shoots of two leafy vegetables at different growth periods in general. The chemical form and bioaccessible fraction of $\mathrm{Cd}$ in the edible blanching tissues were used to calculate the risk of oral intake. The vegetable-induced hazard quotients of lettuce and pak-choi were acceptable, except for pak-choi grown in control without applying BC.
\end{abstract}

Keywords: bioaccessibility; cadmium; chemical form; husk biochar; risk assessment

\section{Introduction}

Many illegal factories arbitrarily discharge wastewater into irrigation channels, where farmers unknowingly draw contaminated water for paddy rice cultivation, causing many farmlands in Taiwan to be contaminated with potential toxic elements (PTEs) [1]. If the total concentration of PTEs in the soil is above the control standard stipulated by the Soil and Groundwater Pollution Remediation Act (SGWPR Act) of Taiwan, crops should be removed to prevent human consumption [2]. However, when the total concentration of PTEs in the soil is slightly above the monitoring standard and below the control standard, crop safety must be emphasized, especially concerning the pathway of oral intake of vegetables.

Cadmium (Cd), a non-essential PTE, is one of the most toxic substances to plants and animals because it is easily transferrable from soil to plant $[3,4]$. The accumulation of $\mathrm{Cd}$ in the edible tissues of crops poses serious concerns to the trophic risk of $\mathrm{Cd}$ transfer along a food chain [5]. Because of the carcinogenic and adverse effects of $\mathrm{Cd}$ on biological processes, the International Agency of Research on Cancer and the United States Environmental Protection Agency classified Cd into Group 1 and 
Class B, respectively [6]. Excessive concentration of Cd damaged mesophyll cells and epidermal cells in wheats [7] and resulted in the reduction of photosynthesis and chlorophyll content $[8,9]$. Once the roots uptake PTEs, plants can decrease the toxicity of PTEs by cell wall deposition and vacuolar compartmentation [10-13]. Cell walls are mainly composed of pectin, protein, cellulose, and semi-cellulose [14], and functional groups in cell walls could restrict PTEs into the cytoplasm, which prevents the protoplast from being poisoned [15].

The chemical forms can be of help in understanding the tolerance and mechanisms of PTE detoxification in plants. These chemical forms include inorganic $\left(\mathrm{F}_{\mathrm{E}}\right)$, water-soluble $\left(\mathrm{F}_{\mathrm{W}}\right)$, pectate- and protein-integrated $\left(\mathrm{F}_{\mathrm{NaCl}}\right)$, undissolved phosphate $\left(\mathrm{F}_{\mathrm{HAc}}\right)$, oxalate $\left(\mathrm{F}_{\mathrm{HCl}}\right)$, and residual $\left(\mathrm{F}_{\mathrm{R}}\right)$ forms $[16,17]$. Among them, $\mathrm{F}_{\mathrm{E}}$ and $\mathrm{F}_{\mathrm{W}}$ have high mobility and thus are easily translocated to other plant organs [18]. Many studies revealed that $\mathrm{F}_{\mathrm{NaCl}}$ was related to adjusting Cd stress in ramie, cabbage and American pokeweed [18-20]. There was also a positive linear correlation between Cd concentration in the $\mathrm{F}_{\mathrm{NaCl}}$ and $\mathrm{F}_{\mathrm{HAc}}$ forms, and that in the shoot, which revealed that chemical forms can be used to predict the accumulation of $\mathrm{Cd}$ in the shoot [21].

Many soil amendments (e.g., compost, phosphate fertilizer, and organic matter) have been used for remediation of PTE-contaminated soil [22,23]. For instance, Liu et al. [24] found that the co-application of vermicompost and selenium could alleviate the $\mathrm{Cd}$ accumulation in rice. The presence of organic matter redistributed the PTE to less-available forms and thus ameliorated its toxicity to plants [25]. The solubility of PTE is high in an acidic $\mathrm{pH}$, whereas addition of lime and biochar (BC) can increase the soil $\mathrm{pH}$ and thus can decrease the bioavailability [26-28]. Biochars are porous, low density, and carbon-rich solid products from the pyrolysis of waste biomass. Xu et al. [29] revealed that adding $\mathrm{BC}$ s to contaminated paddy soil improved the transformation of $\mathrm{Cd}$ from the acid-soluble fraction to the oxidizing and residual fractions. $\mathrm{BCs}$ also had a great capacity to reduce the percentage of inorganic and water-soluble fractions in lettuce roots grown in Cd-contaminated soil [30]. Additionally, BCs mainly increased undissolved cadmium phosphate and thus increased the $\mathrm{Cd}$ accumulation in pokeweed root [31].

In this study, different varieties or cultivars of lettuce and pak-choi were grown in soil dominantly contaminated with Cd. Husk BC was applied to replenish nitrogen to the recommended amount and to decrease the soil acidity. The objective of this study was to understand the effect of the application of husk $\mathrm{BC}$ on the accumulation, translocation, and chemical forms of $\mathrm{Cd}$ in two leafy vegetables. In addition, the vegetable-induced hazard quotient $\left(\mathrm{HQ}_{\mathrm{V}}\right)$ was calculated via the chemical form and artificial digestant extractable concentration of $\mathrm{Cd}$ in the blanched edible parts to assess the risk from oral intake.

\section{Materials and Methods}

Experimental soil samples were collected from the surface layer $(0-30 \mathrm{~cm})$ of a Cd-contaminated site in central Taiwan because the soil $\mathrm{Cd}$ resulted from the use of irrigation water mainly accumulated in the top $30 \mathrm{~cm}$ [32]. Soil samples were air-dried, ground, passed through a 10-mesh stainless steel sieve, and then homogenized before analysis. Their basic properties were then analyzed, including $\mathrm{pH}$ [33], electrical conductivity (EC) [34], content of organic carbon (OC) [35], cation exchange capacity (CEC) [36], texture [37], and total concentration of $\mathrm{Cd}$, chromium (Cr), nickel (Ni), and zinc ( $\mathrm{Zn})$ [38]. Other soil samples were homogenized and used for a pot experiment. The total concentrations of nitrogen, phosphorus, and potassium in the BC were analyzed in accordance with the methods described by Bremner [39], Kuo [40], and Helmke and Sparks [41], respectively. Two treatments used in this study were CK (control without applying biochar) and BC, which applied husk BC to replenish nitrogen to the recommended amount. For lettuce and pak-choi, 46,920 and 98,000 kg/ha of BC was applied, respectively. In total, $1.0 \mathrm{~kg}$ of soil samples or mixture was added to each pot, and seeds of two pak-choi-Brassica chinensis L. var. Chinensis (PCC) and Brassica chinensis L. cv. Wrinkled leaf (PCW) - and two lettuce-Lactuca sative L. cv. Chinese (LSC) and Lactuca sative L. var. Sative (LSS)-were sown. The above vegetables were selected because of their importance in human diets [42] 
and they are the most commonly consumed leafy vegetables in Taiwan [43]. The pots were translocated to a phytotron $\left(25.1 \pm 0.4{ }^{\circ} \mathrm{C}\right.$, relative humidity $\left.61.2 \pm 5.7 \%\right)$. Soil moistures were determined every two to three days, and remained at $60-80 \%$ of water-holding capacity by replenished deionized water.

All leafy vegetables were harvested 35, 42, and 49 days (D35, D42, and D49) after sowing and divided into roots and shoots. At this time, the shoot heights were measured and the chlorophyll content of the largest extended leaf was determined using a Konica Minolta SPAD-502 and recorded as SPAD (soil plant analyzer development) readings. Fresh plant tissues were rinsed with tap water and then deionized water. To remove the adsorbed $\mathrm{Cd}$, the roots were soaked in $20 \mathrm{mM}$ of $\mathrm{Na}_{2}$-EDTA for 15 min. The Cd compartmentalized in different chemical forms in the shoots was analyzed using a sequential extraction in accordance with the methods described by Lai [21]. Six chemical forms were extracted in the following sequence, with the corresponding agents: inorganic $\mathrm{Cd}\left(\mathrm{F}_{\mathrm{E}}\right)$ extracted by $80 \%$ alcohol, water-soluble $\mathrm{Cd}\left(\mathrm{F}_{\mathrm{W}}\right)$ extracted by deionized water, pectate- and protein-integrated $\mathrm{Cd}\left(\mathrm{F}_{\mathrm{NaCl}}\right)$ extracted by $1 \mathrm{M} \mathrm{NaCl}$, undissolved $\mathrm{Cd}$ phosphate $\left(\mathrm{F}_{\mathrm{HAc}}\right)$ extracted by $2 \% \mathrm{CH}_{3} \mathrm{COOH}$, Cd oxalate $\left(\mathrm{F}_{\mathrm{HCl}}\right)$ extracted by $0.6 \mathrm{M} \mathrm{HCl}$, and residual $\mathrm{Cd}\left(\mathrm{F}_{\mathrm{R}}\right)$ digested with aqua regia. All the other plant tissues were oven-dried at $65^{\circ} \mathrm{C}$ for $72 \mathrm{~h}$ and then weighed (dry weight) before grinding (Rong Tsong Precision Tech. Co., Taichung, Taiwan), and then digested with $\mathrm{HNO}_{3} / \mathrm{HClO}_{4}(v / v=3 / 1)$. The $\mathrm{Cd}$ concentration in the digestant was determined using a flame atomic absorption spectrophotometer (FAAS, Perkin Elmer AAnalyst 200, Waltham, MA, USA).

Soil samples of different treatments were air-dried, ground, passed through a 10-mesh stainless steel sieve, and then homogenized before analysis. The available concentration of $\mathrm{Cd}$ in the soils was extracted with $0.1 \mathrm{~N} \mathrm{HCl}$ [44] and $0.05 \mathrm{~N}$ EDTA [45]. A BCR sequestration extraction based on the European Community Bureau of Reference [46] was also conducted to understand the Cd distribution in the different fractions. These four fractions include the exchangeable fraction (F-I), organic matter-bounding fraction (F-II), oxide-bounding fraction (F-III), and residual fraction (F-IV).

Statistical analysis was performed using the Statistical Package for the Social Sciences (SPSS, Armonk, NY, USA). Analysis of variance (ANOVA) was used to test the effect of different treatments on the different growth exhibitions and soil properties. The least significant difference (LSD) test was used to compare the significant differences of $\mathrm{pH}, \mathrm{EC}$, available $\mathrm{Cd}$ concentration, $\mathrm{Cd}$ distribution in the different fractions, four growth exhibitions, $\mathrm{Cd}$ concentration in the roots and shoots, bioconcentration factor $(\mathrm{BCF}=$ ratio of root concentration to soil concentration), and transfer factor $(\mathrm{TF}=\mathrm{shoot}$ concentration to root concentration) between treatments $(p<0.05)$.

\section{Results}

\subsection{Soil Properties}

The total concentrations of $\mathrm{Cd}, \mathrm{Cr}, \mathrm{Ni}$, and $\mathrm{Zn}$ were in the ranges of 10-13, 51-60, 126-146, and 61-68 mg/kg, respectively. For the four PTEs analyzed, only Cd and Ni were beyond the control standard (Cd $5 \mathrm{mg} / \mathrm{kg}, \mathrm{Ni} 130 \mathrm{mg} / \mathrm{kg}$ ) of farmland based on the SGWPR Act of Taiwan and could cause the samples to be regarded as $\mathrm{Cd}$ - and Ni-contaminated soils. However, only $\mathrm{Cd}$ accumulation in the lettuce and pak-choi was discussed in this paper because of following reasons. First, the total concentration of $\mathrm{Cd}$ was beyond not only the Canadian soil quality guideline $(1.4 \mathrm{mg} / \mathrm{kg}) \mathrm{but}$ also the Soil Contamination Warming Limit (4 mg/kg) and Counterplan Limit (12 mg/kg) of Korea for agricultural lands. Moreover, $\mathrm{Cd}$ has higher bioaccessibility in comparison with Ni [47] and is also the only one PTE regulated by the Office of the Journal of the European Union [48] among four soil PTEs analyzed in this study. The BC used in this study had very strong alkalinity and high EC. Its $\mathrm{pH}$ and EC were $10.54 \pm 0.06$ and $1.82 \pm 0.08 \mathrm{dS} / \mathrm{m}$, respectively. Total concentrations of nitrogen, phosphorus, and potassium in the BC were $0.24 \pm 0.05 \%, 0.61 \pm 0.10 \%$, and $1.59 \pm 0.09 \%$, respectively. For the four PTEs analyzed in this study, the BC only had $1.40 \pm 1.99$ and $10.42 \pm 2.25 \mathrm{mg} / \mathrm{kg}$ of Cd and Zn, respectively, and the total concentrations of $\mathrm{Cr}$ and $\mathrm{Ni}$ were not detectable. 
The application of $\mathrm{BC}$ was able to significantly increase the soil $\mathrm{pH}$ and $\mathrm{EC}$ in comparison with $\mathrm{CK}$. The BC treatments raised or significantly $(p<0.05)$ raised $\mathrm{pH}$ from $6.6-6.8$ and $6.9-7.0$ to $6.8-7.1$ and 7.6-8.0 for the lettuce and pak-choi cultivated soils, respectively (Table 1). Because of the high EC of $B C$, the soil EC also increased or significantly $(p<0.05)$ increased from $0.03-0.08(C K)$ to $0.06-0.18$ $\mathrm{dS} / \mathrm{m}$ under the $\mathrm{BC}$ treatment.

Table 1. Effect of different treatments on the $\mathrm{pH}$, electrical conductivity, two chemical agents extractable $\mathrm{Cd}$ concentrations, and Cd's distribution in the different fractions.

\begin{tabular}{|c|c|c|c|c|c|c|c|c|}
\hline \multirow{3}{*}{ Treatment $^{2}$} & \multicolumn{8}{|c|}{ Soil Property and Cd Concentration ${ }^{1}$} \\
\hline & \multirow{2}{*}{$\mathrm{pH}$} & \multirow{2}{*}{$\begin{array}{c}\text { Electrical } \\
\text { Conductivity }\end{array}$} & \multicolumn{2}{|c|}{ Extracting Agent } & \multicolumn{4}{|c|}{ BCR Sequestration Extraction ${ }^{3}$} \\
\hline & & & $0.1 \mathrm{~N} \mathrm{HCl}$ & $\begin{array}{l}0.05 \mathrm{~N} \\
\text { EDTA }\end{array}$ & F-I & F-II & F-III & F-IV \\
\hline & & $\mathrm{dS} / \mathrm{m}$ & \multicolumn{2}{|c|}{$\mathrm{mg} / \mathrm{kg}$} & \multicolumn{4}{|c|}{$\%$} \\
\hline PCC-CK & $6.90 \pm 0.15 b$ & $0.03 \pm 0.00 \mathrm{~b}$ & $6.63 \pm 0.24 a$ & $6.81 \pm 0.25 a$ & $55.99 \pm 0.39 b$ & $26.37 \pm 0.23 c$ & $16.18 \pm 0.22 b$ & $1.46 \pm 0.04 \mathrm{~b}$ \\
\hline PCC-BC & $7.93 \pm 0.18 a$ & $0.12 \pm 0.02 \mathrm{a}$ & $6.98 \pm 0.61 \mathrm{a}$ & $7.03 \pm 0.38 \mathrm{a}$ & $64.67 \pm 0.31 \mathrm{a}$ & $26.61 \pm 0.07 \mathrm{c}$ & $7.63 \pm 0.10 c$ & $1.08 \pm 0.03 c$ \\
\hline PCW-CK & $6.90 \pm 0.20 b$ & $0.05 \pm 0.01 b$ & $7.23 \pm 0.68 \mathrm{a}$ & $7.01 \pm 0.39 \mathrm{a}$ & $52.57 \pm 0.34 c$ & $31.00 \pm 0.10 \mathrm{a}$ & $16.44 \pm 0.17 \mathrm{ab}$ & ND \\
\hline PCW-BC & $7.62 \pm 0.46 a$ & $0.17 \pm 0.06 \mathrm{ab}$ & $6.91 \pm 0.56 \mathrm{a}$ & $6.27 \pm 0.34 b$ & $51.93 \pm 0.29 \mathrm{~d}$ & $29.91 \pm 0.15 b$ & $16.56 \pm 0.22 \mathrm{a}$ & $1.60 \pm 0.03 \mathrm{a}$ \\
\hline LSC-CK & $6.69 \pm 0.11 \mathrm{a}$ & $0.07 \pm 0.02 \mathrm{a}$ & $7.70 \pm 0.62 \mathrm{a}$ & $7.41 \pm 0.85 \mathrm{a}$ & $61.34 \pm 0.27 a$ & $20.86 \pm 0.19 c$ & $17.80 \pm 0.23 b$ & ND \\
\hline LSC-BC & $6.81 \pm 0.16 a$ & $0.16 \pm 0.08 \mathrm{a}$ & $7.00 \pm 0.64 a$ & $6.82 \pm 0.56 \mathrm{a}$ & $37.70 \pm 0.39 \mathrm{~d}$ & $45.26 \pm 0.11 \mathrm{a}$ & $17.04 \pm 0.22 c$ & ND \\
\hline LSS-CK & $6.77 \pm 0.11 \mathrm{a}$ & $0.05 \pm 0.01 \mathrm{a}$ & $6.90 \pm 0.88 \mathrm{a}$ & $7.62 \pm 0.30 \mathrm{a}$ & $38.90 \pm 0.28 c$ & $36.51 \pm 0.32 b$ & $21.84 \pm 0.16 a$ & $2.76 \pm 0.05$ \\
\hline LSS-BC & $7.02 \pm 0.23 a$ & $0.06 \pm 0.00 \mathrm{a}$ & $6.55 \pm 1.18 \mathrm{a}$ & $6.64 \pm 0.94 a$ & $57.32 \pm 0.44 b$ & $20.88 \pm 0.12 c$ & $21.80 \pm 0.25 a$ & ND \\
\hline
\end{tabular}

${ }^{1}$ Mean \pm standard deviation; ND: not detectable; The same lowercase letter indicates no significant difference between treatments for the same soil property and the same leafy vegetable. ${ }^{2}$ PCC, PCW, LSC, and LSS are Brassica chinensis L. var. Chinensis, Brassica chinensis L. cv. Wrinkled leaf, Lactuca sative L. cv. Chinese, and Lactuca sative L. var. Sative, respectively; CK: control without applying husk biochar; BC: applying 46,920 and 98,000 kg/ha of husk biochar for lettuce and pak-choi, respectively. ${ }^{3}$ F-I, F-II, F-III, and F-IV are exchangeable fraction, organic matter-bounding fraction, oxide-bounding fraction, and residual fraction, respectively.

\subsection{Soil Cd Fraction and Growth Exhibition}

Even through the $\mathrm{BC}$ treatment raised the soil $\mathrm{pH}$ in comparison with $\mathrm{CK}$, the soil $\mathrm{Cd}$ fractions only slightly changed except for those of the lettuce. Regardless of treatments and crops, F-I was the primary fraction of $\mathrm{Cd}$ in the soils, and accounted for $37-65 \%$ of the total concentration in general (Table 1). In comparison with $\mathrm{CK}$, the $\mathrm{BC}$ treatment significantly $(p<0.05)$ changed the $\mathrm{Cd}$ in F-I and F-II of lettuce. For LSS treated with BC, the Cd proportion of F-I significantly $(p<0.05)$ increased, but F-II significantly $(p<0.05)$ decreased compared with CK. For LSC treated with BC and in contrast with $\mathrm{CK}$, however, the Cd in the F-I significantly $(p<0.05)$ decreased and F-II significantly $(p<0.05)$ increased. The BC treatment did not significantly change the Ni proportion in the different fractions (detailed data not shown). F-IV was the primary fraction of $\mathrm{Ni}$ in general and accounted for $57-63 \%$ of the total $\mathrm{Ni}$ in the soils. Besides sequence extraction, $0.1 \mathrm{~N} \mathrm{HCl}$ and $0.05 \mathrm{~N}$ EDTA were used to extract the available concentration of $\mathrm{Cd}$ and $\mathrm{Ni}$ in the soils. Approximately $58-68 \%$ and $56-69 \%$ of the total $\mathrm{Cd}$ in the soils could be extracted by $0.1 \mathrm{~N} \mathrm{HCl}$ and $0.05 \mathrm{~N}$ EDTA, respectively. Because most of the Ni was presented in the F-IV fraction, $0.1 \mathrm{~N} \mathrm{HCl}$ and $0.05 \mathrm{~N}$ EDTA only extracted $10-15 \%$ and $9-13 \%$ of the total $\mathrm{Ni}$ in the soils, respectively. In comparison with $\mathrm{CK}$, the $\mathrm{BC}$ treatment did not significantly decrease the two chemical agents' extractable $\mathrm{Cd}$ and Ni concentrations in the soils in general.

Compared to CK treatments, the root length, shoot height, shoot fresh weight, and SPAD reading increased under BC treatment in general (Table 2). However, most of the differences were not statistically significant. These results revealed that BC treatment promoted the growth of PCC in general. 
Table 2. The growth exhibitions (mean \pm standard deviation) of pak-choi and lettuce grown in the contaminated soils amended with or without applying husk biochar ${ }^{1}$.

\begin{tabular}{|c|c|c|c|c|c|c|c|c|}
\hline \multirow{2}{*}{$\begin{array}{l}\text { Growth } \\
\text { Exhibition }\end{array}$} & \multicolumn{4}{|c|}{ Pak-choi $^{2}$} & \multicolumn{4}{|c|}{ Lettuce $^{2}$} \\
\hline & PCC-CK & PCC-BC & PCW-CK & PCW-BC & LSC-CK & LSC-BC & LSS-CK & LSS-BC \\
\hline Root length $(\mathrm{cm})$ & $4.61 \pm 1.49 a$ & $8.26 \pm 3.52 a$ & $3.59 \pm 0.20 \mathrm{a}$ & $4.66 \pm 0.95 a$ & $7.59 \pm 1.30 \mathrm{a}$ & $6.96 \pm 0.21 \mathrm{a}$ & $7.71 \pm 0.45 a$ & $8.09 \pm 1.38 \mathrm{a}$ \\
\hline Shoot height $(\mathrm{cm})$ & $10.32 \pm 2.75 a$ & $12.19 \pm 0.67 a$ & 12.19 & 11.56 & $8.74 \pm$ & $7.58 \pm 0.88 c$ & $15.47 \pm 0.39 a$ & $17.99 \pm 2.19 \mathrm{ab}$ \\
\hline $\begin{array}{l}\text { Shoot fresh weight } \\
\text { (g/plant) }\end{array}$ & $0.48 \pm 0.07 a$ & $1.03 \pm 0.12 \mathrm{a}$ & $0.51 \pm 0.28 \mathrm{a}$ & $0.78 \pm 0.56 a$ & $0.52 \pm 0.09 \mathrm{c}$ & $0.90 \pm 0.23 b$ & $0.35 \pm 0.08 c$ & $1.51 \pm 0.22 \mathrm{a}$ \\
\hline SPAD reading ${ }^{3}$ & $10.48 \pm 1.70 \mathrm{ab}$ & $7.84 \pm 0.60 c$ & $9.71 \pm 0.92 b c$ & $11.96 \pm 1.14 \mathrm{a}$ & $14.32 \pm 1.97 \mathrm{a}$ & $14.41 \pm 1.74 a$ & $12.42 \pm 0.50 a$ & $14.91 \pm 0.30 \mathrm{a}$ \\
\hline
\end{tabular}

${ }^{1}$ The same lowercase letter indicates no significant difference between treatments for the same leafy vegetable and the same growth exhibition. ${ }^{2}$ The meanings of abbreviations are the same as in Table $1 .{ }^{3}$ SPAD reading: soil plant analyzer development reading.

\subsection{Cd Accumulation}

The concentrations of PTEs in the lettuce and pak-choi at three different growth periods (D35, D42, and D49) are shown in Figures 1 and 2. The Cd concentrations in the roots of LSC cultivars grown in CK for 35-49 days were in the range of 3.1-11.0 mg/kg, which were 1.4 to 6.4 times higher than that accumulated in the roots of LSS (Figure 1). In the shoots of different growing periods of lettuce, LSC also accumulated higher concentrations of Cd compared with LSS. The Cd concentrations in the shoots of LSC and LSS grown in CK of D35-D49 were in the ranges of 2.1-6.9 and 1.8-3.1 mg/kg, respectively. The LSC accumulated higher concentrations of $\mathrm{Cd}$ both in roots and shoots compared with LSS. Relative to LSS, the accumulated Cd concentrations in the edible parts of LSC were 1.7-3.5 times higher, which revealed that LSC can be regarded as a high-Cd-accumulation cultivar of lettuce. The PCW cultivar accumulated higher concentrations of $\mathrm{Cd}$ in the roots and shoots in comparison with PCC in general (Figure 2). The accumulated Cd concentrations in the roots of PCW and PCC growing for D35-D49 were in the ranges of 6.6-32.3 and 2.9-12.7 mg/kg, respectively. In the shoots of PCW and PCC, the Cd concentrations of D35-D49 were $3.4-8.9$ and $3.4-7.8 \mathrm{mg} / \mathrm{kg}$, respectively.

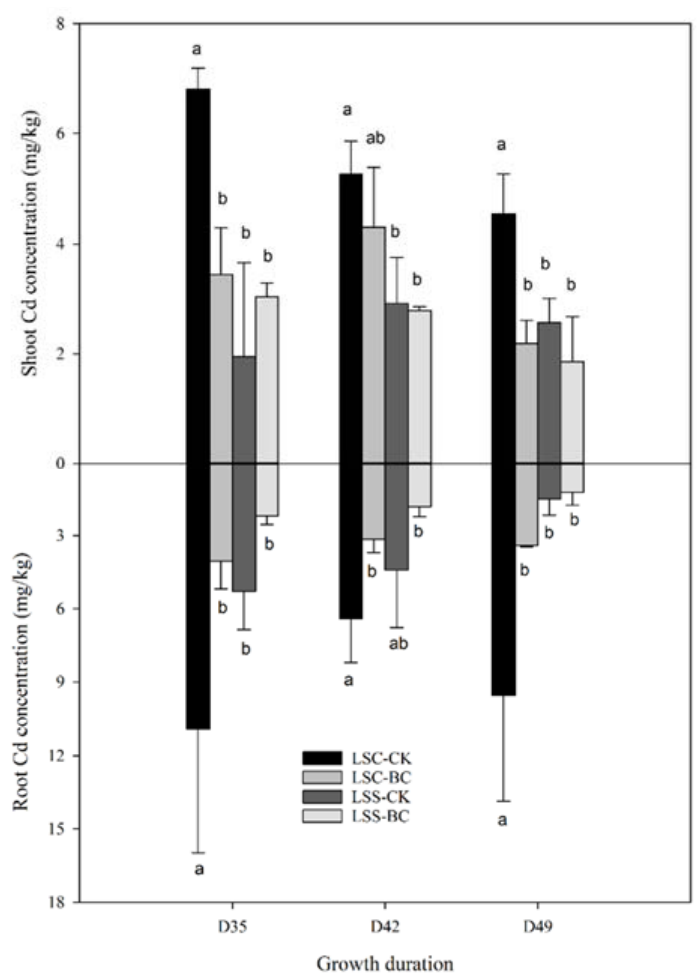

Figure 1. Effect of husk biochar treatment on the Cd accumulation in the roots and shoots of lettuce. The meanings of abbreviations are the same as in Table 1. The same lowercase letter indicates no significant difference between treatments for the same growth period. 


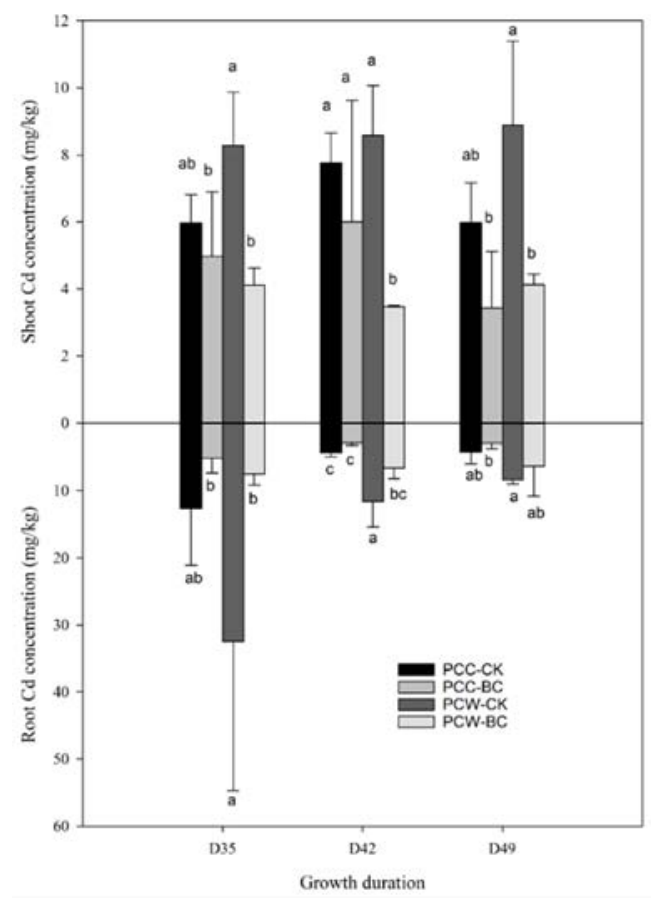

Figure 2. Effect of husk biochar treatment on the $\mathrm{Cd}$ accumulation in the roots and shoots of pak-choi. The meanings of abbreviations are the same as in Table 1. The same lowercase letter indicates no significant difference between treatments for the same growth period.

Except for LSS-D35, in comparison with CK, the BC treatments decreased or significantly $(p<0.05)$ decreased the accumulation of $\mathrm{Cd}$ in the roots and shoots of lettuce (Figure 1) and pak-choi (Figure 2). This phenomenon was especially true for the LSC variety, which had high accumulating capacity compared with LSS. Relative to CK, the Cd concentrations accumulated in the roots and shoots of LSC under BC treatments decreased 50-64\% and 18-52\%, respectively, in comparison with CK. Whether treating with $\mathrm{BC}$ or not, higher $\mathrm{Cd}$ concentrations were found in the roots and shoots of pak-choi compared with lettuce at different growth periods. Under the BC treatments, most of the $\mathrm{Cd}$ concentrations in the roots and shoots of pak-choi decreased $24-77 \%$ and $16-60 \%$, respectively, in comparison with $\mathrm{CK}$.

\subsection{Chemical Form}

According to the standard for the Tolerance of Heavy Metals in Plant Origin of Taiwan for leafy vegetables, $0.2 \mathrm{mg} / \mathrm{kg} \cdot \mathrm{FW}$, most of the Cd concentrations in the edible parts of lettuce and pak-choi were beyond this standard if the water content of them was $90 \%$. Whether treating with BC or not, $\mathrm{Cd}$ was mainly compartmentalized in the $\mathrm{F}_{\mathrm{E}}$ chemical form in the shoots of lettuce and pak-choi. Approximately $94-98 \%$ and $82-98 \%$ of the Cd accumulated in the shoots of lettuce and pak-choi, respectively, were compartmentalized in the $\mathrm{F}_{\mathrm{E}}$ at D42-D49 (Figure 3). 

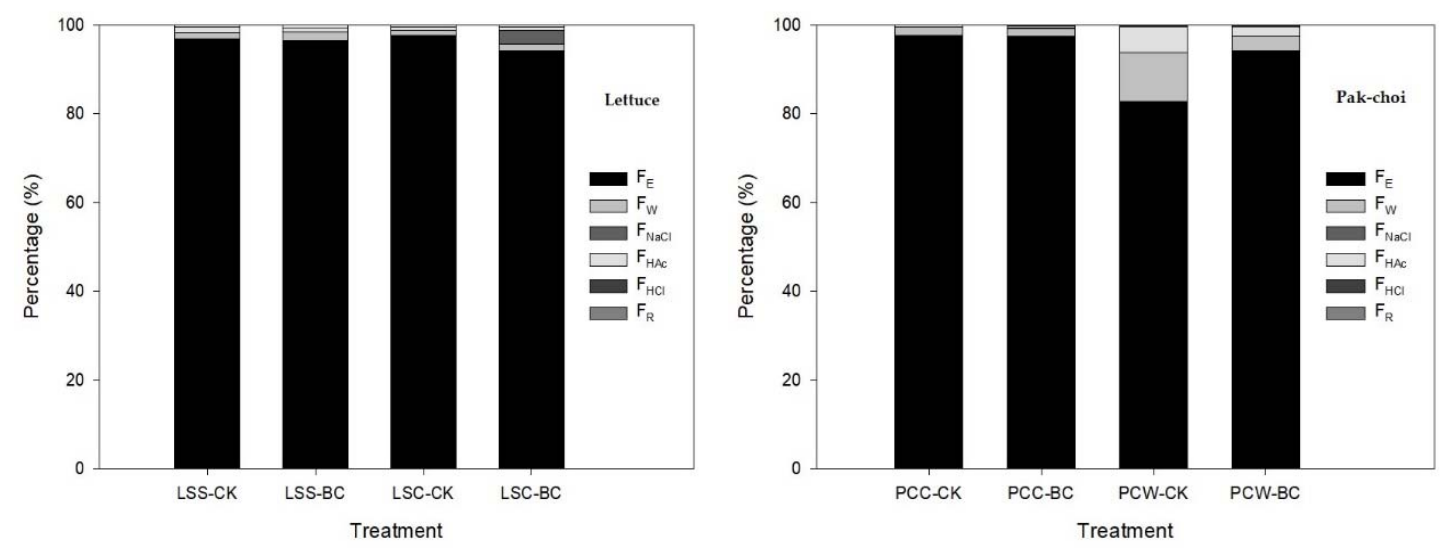

Figure 3. Effect of husk biochar treatment on the chemical form of $\mathrm{Cd}$ in the shoots of pak-choi and lettuce. The meanings of treatments are the same as in Table 1. $\mathrm{F}_{\mathrm{E}}, \mathrm{F}_{\mathrm{W}}, \mathrm{F}_{\mathrm{NaCl}}, \mathrm{F}_{\mathrm{HAc}}, \mathrm{F}_{\mathrm{HCl}}$, and $\mathrm{F}_{\mathrm{R}}$ are inorganic, water-soluble, pectate- and protein-integrated, undissolved phosphate, oxalate, and residual chemical forms, respectively.

\section{Discussion}

For the three different growing periods, the accumulated Cd in the edible parts of LSC and PCW grown in CK were in the ranges of 4.5-6.9 and 8.2-8.9 mg/kg, respectively (Figures 1 and 2). These values were 1.7-3.5 and 1.1-1.5 times higher than LSS and PCC, respectively. Further results revealed that the accumulating capacity of Cd of LSC and PCW was stronger than LSS and PCC. Moreover, the lettuce and pak-choi accumulated almost constant concentration of $\mathrm{Cd}$ in the edible parts regardless of the growing period once planted in the Cd-contaminated soils. The experimental results of this study are in agreement with Lai and Chen [49].

$\mathrm{BCF}$ was used to evaluate the accumulation of $\mathrm{Cd}$ in the edible parts of two leafy vegetables at $\mathrm{D} 49$ (Table 3). $\mathrm{BCF}_{\mathrm{R}}$ and $\mathrm{BCF}_{\mathrm{S}}$ are the ratio of root and shoot concentration to soil concentration, respectively. The LSC accumulated more Cd than LSS, and the $\mathrm{BCF}_{\mathrm{R}}$ of LSC at D49 was 6.1 and 2.6 times higher than LSS grown in CK and $B C$, respectively. All the $B C F_{R}$ and $B C F_{S}$ of lettuce grown in $C K$ were less than 0.9 , and there was a $25-68 \%$ and $32-58 \%$ decrease in $\mathrm{BCF}_{\mathrm{R}}$ and $\mathrm{BCF}_{\mathrm{S}}$, respectively, under $\mathrm{BC}$ treatment in comparison with $\mathrm{CK}$. Whether applying $\mathrm{BC}$ or not, the $\mathrm{BCF}_{\mathrm{S}}$ of LSC was 1.1-1.8 times higher than that of LSS. This phenomenon reveals that LSC can accumulate higher Cd concentrations in the edible parts and also shows higher risk through oral consumption than LSS.

The PCW accumulated more Cd than PCC, and the $\mathrm{BCF}_{\mathrm{R}}$ of PCW at $\mathrm{D} 49$ was 1.9 and 2.3 times higher than PCC grown in $C K$ and $B C$, respectively. All the $\mathrm{BCF}_{\mathrm{R}}$ and $\mathrm{BCF}_{\mathrm{S}}$ of pak-choi grown in $\mathrm{CK}$ were less than 0.9 , and there was a $27-55 \%$ and $45-50 \%$ decrease in $\mathrm{BCF}_{\mathrm{R}}$ and $\mathrm{BCF}_{\mathrm{S}}$, respectively, under $\mathrm{BC}$ treatment compared with $\mathrm{CK}$. Even though the $\mathrm{BCF}_{\mathrm{R}}$ of $\mathrm{PCW}$ was higher than $\mathrm{PCC}$, the $\mathrm{BCF}_{\mathrm{S}}$ of PCW grown in different treatments was $57-75 \%$ that of PCC. This phenomenon reveals that the Cd accumulated in the roots of PCW was not efficiently upwardly transferred to shoots and thus had lower $\mathrm{BCF}_{\mathrm{S}}$ compared with PCC.

Besides $\mathrm{BCF}$, TF was used to evaluate the transfer of $\mathrm{Cd}$ from roots to edible parts of lettuce and pak-choi (Table 3). Approximately all the TF values of LSC and PCW, with higher BCF $_{R}$ and $\mathrm{BCF}_{\mathrm{S}}$ under different growth periods and treatments, were below unity in general. For LSS and PCC, however, TF values were higher than LSC and PCC, respectively, and were in the ranges of $0.3-1.8$ and 0.4-2.1, respectively. Further results reveal that the Cd uptake by LSC and PCW grown in CK were mainly accumulated in the non-edible parts, regardless of growing periods. However, the TF values of LSS and PCC grown in BC at D42 and D49 reached 1.1-2.1. This result reveals that the accumulated $\mathrm{Cd}$ would transfer to shoots more easily than the other two varieties, even grown in BC. Except for LSS-D49, the BC treatment was efficient in increasing the TF of LSS and LSC in comparison with CK, regardless of growth periods. This result revealed that even the $\mathrm{BC}$ decreased the accumulated $\mathrm{Cd}$ 
concentration in the roots; on the contrary, BC increased the upward translocation of Cd from roots to shoots in two lettuce varieties because of Cd's high mobility compared with other PTEs.

Table 3. The bioconcentration factor (BCF), transfer factor (TF), average daily dose (ADD), and hazard quotient $(\mathrm{HQ})$ calculated using three different methods ${ }^{1}$.

\begin{tabular}{|c|c|c|c|c|c|c|c|c|c|}
\hline \multirow[t]{2}{*}{ Treatment $^{2}$} & \multirow[t]{2}{*}{$\mathrm{BCF}_{\mathrm{R}}{ }^{3}$} & \multirow[t]{2}{*}{$\mathrm{BCF}_{\mathrm{S}}{ }^{3}$} & \multirow[t]{2}{*}{$\mathrm{TF}^{3}$} & \multicolumn{3}{|c|}{$\begin{array}{c}\text { Average Daily Dose }{ }^{4} \\
\text { (ADD } ; \mu \mathrm{g} / \mathrm{kg} \cdot \mathrm{BW} / \text { day) }\end{array}$} & \multicolumn{3}{|c|}{ Hazard Quotient $\left(\mathrm{HQ}_{\mathrm{v}}\right)^{4}$} \\
\hline & & & & $\mathrm{ADD}_{\mathrm{v}}-\mathrm{TC}$ & $\mathrm{ADD}_{\mathrm{v}}-\mathrm{CF}$ & $\mathrm{ADD}_{\mathrm{v}}-\mathrm{BF}$ & $\mathrm{HQ}_{\mathrm{v}}-\mathrm{TC}$ & $\mathrm{HQ}_{\mathrm{v}}-\mathrm{CF}$ & $\mathrm{HQ}_{\mathrm{v}}-\mathrm{BF}$ \\
\hline PCC-CK & $0.40 \pm 0.17 a b$ & $0.57 \pm 0.11 \mathrm{a}$ & $1.43 \pm 0.67 a$ & 0.66 & 0.002 & 0.15 & 7.88 & 0.02 & 1.73 \\
\hline PCC-BC & $0.25 \pm 0.06 b$ & $0.29 \pm 0.14 a$ & $1.15 \pm 0.64 a$ & 0.37 & 0.001 & 0.08 & 4.42 & 0.02 & 0.97 \\
\hline PCW-CK & $0.78 \pm 0.06 a$ & $0.82 \pm 0.23 a$ & $1.06 \pm 0.23 a$ & 0.60 & 0.019 & 0.13 & 7.16 & 0.22 & 1.57 \\
\hline PCW-BC & $0.57 \pm 0.40 \mathrm{ab}$ & $0.37 \pm 0.03 a$ & $0.65 \pm 0.49 a$ & 0.29 & 0.004 & 0.06 & 3.43 & 0.05 & 0.75 \\
\hline LSC-CK & $0.89 \pm 0.40 \mathrm{a}$ & $0.42 \pm 0.07 \mathrm{a}$ & $0.47 \pm 0.37 \mathrm{~b}$ & 0.34 & 0.002 & 0.08 & 4.07 & 0.03 & 0.90 \\
\hline LSC-BC & $0.28 \pm 0.01 b$ & $0.18 \pm 0.04 b$ & $0.64 \pm 0.13 b$ & 0.20 & 0.004 & 0.04 & 2.41 & 0.05 & 0.53 \\
\hline LSS-CK & $0.14 \pm 0.06 b$ & $0.25 \pm 0.04 b$ & $1.70 \pm 0.49 a$ & 0.26 & 0.002 & 0.06 & 3.04 & 0.03 & 0.67 \\
\hline LSS-BC & $0.11 \pm 0.05 b$ & $0.17 \pm 0.07 b$ & $1.53 \pm 0.79 a$ & 0.29 & 0.002 & 0.06 & 3.46 & 0.03 & 0.76 \\
\hline
\end{tabular}

In comparison with $\mathrm{CK}$, the $\mathrm{BC}$ treatment did not have significant effects on changing the $0.1 \mathrm{~N} \mathrm{HCl}$ and $0.05 \mathrm{~N}$ EDTA extractable Cd concentrations (Table 1), and also the chemical form of $\mathrm{Cd}$ compartmentalized in the shoots of lettuce and pak-choi (detail data not shown). However, the accumulated $\mathrm{Cd}$ concentration in the roots and shoots of lettuce and pak-choi grown under $\mathrm{BC}$ treatment at different growth periods were decreased or significantly decreased $(p<0.05)$ compared with CK (Figures 1 and 2).

Antoniadis et al. [50] reported that the vegetable-induced average daily dose $\left(\mathrm{ADD}_{\mathrm{v}}\right)$ and vegetable-induced hazard quotient $\left(\mathrm{HQ}_{\mathrm{v}}\right)$ can be calculated using Equations (1) and (2), respectively, where $C_{p}$ is the $C d$ concentration $(\mathrm{mg} / \mathrm{kg})$ in the edible parts of vegetables. The mean individual daily vegetable consumption (MIDVC) in Taiwan during 2013-2016 was $0.133 \mathrm{~kg} / \mathrm{day}$ based on the Report on the Nutrition and Health Survey and vegetable calorie counts, which can be used to calculate $\mathrm{Cd}$ intake daily per person from vegetables. The tolerable daily intake (TDI) of Cd set by the European Food Safety Authority (EFSA) was $0.36 \mu \mathrm{g} / \mathrm{kg}$. BW/day. Nonetheless, food was the dominant source of $\mathrm{Cd}$ exposure of humans and accounts for approximately $90 \%$ of the intake [51]. Among all foods, approximately $26 \%$ was from vegetables [52], which means that the TDI from vegetables $\left(\mathrm{TDI}_{\mathrm{V}}\right.$ ) is $0.084 \mu \mathrm{g} / \mathrm{kg} \cdot \mathrm{BW} /$ day.

$$
\begin{gathered}
\mathrm{ADD}_{\mathrm{v}}=\frac{\mathrm{C}_{\mathrm{p}} \times \mathrm{MIDVC}}{\mathrm{kg} \cdot \mathrm{BW}} \\
\mathrm{HQ}_{\mathrm{v}}=\frac{\mathrm{ADD}_{\mathrm{v}}}{\mathrm{TDI}_{\mathrm{v}}}
\end{gathered}
$$

Blanching is the most common method in Taiwan for cooking leafy vegetables, and it also decreases the concentration of PTE in thoroughly cooked vegetables. Based on the findings of Lam et al. [47], approximately $50 \%$ of the $\mathrm{Cd}$ accumulated in the water spinach was leached into boiling water. In this study, three methods based on total concentration (TC), chemical form (CF), and bioaccessible fraction (BF) of $\mathrm{Cd}$ in the edible parts of vegetables were used to calculate the $\mathrm{HQ}_{\mathrm{v}}$. The $\mathrm{F}_{\mathrm{E}}$ and $\mathrm{F}_{\mathrm{W}}$ were considered to have a higher mobility than other chemical forms and were easily leached into boiling water. Therefore, the sum of the proportion of the other four chemical forms, i.e., $\mathrm{F}_{\mathrm{NaCl}}, \mathrm{F}_{\mathrm{HAc}}, \mathrm{F}_{\mathrm{HCl}}$, and $F_{R}$, was used to calculate the $\mathrm{HQ}_{\mathrm{v}}$, coded as $\mathrm{HQ}_{\mathrm{v}}-\mathrm{CF}$. Furthermore, approximately $32-55 \%$ (average is $44 \%$ ) of the accumulated $\mathrm{Cd}$ in water spinach could be metabolized by in vitro digestive fluids [47], which reveals that approximately $44 \%$ of the $\mathrm{Cd}$ is bioaccessible and can be absorbed by the human body, coded as $\mathrm{HQ}_{\mathrm{v}}-\mathrm{BF}$. 
Regardless of treatments, the $\mathrm{HQ}_{\mathrm{v}}-\mathrm{TC}, \mathrm{HQ}_{\mathrm{v}}-\mathrm{CF}$, and $\mathrm{HQ}_{\mathrm{v}}$-BF values of usedleafy vegetables at D49 were in the ranges of 2.4-7.9, 0.01-0.3, and 0.5-1.8, respectively (Table 3). Because more than 73\% of the accumulated $\mathrm{Cd}$ was compartmentalized in the $\mathrm{F}_{\mathrm{E}}$ chemical form, which could be leached out of vegetable tissues during blanching, the $\mathrm{HQ}_{\mathrm{v}}-\mathrm{CF}$ values were less than 0.3 in general. The application of $B C$ significantly decreased the $\mathrm{HQ}_{\mathrm{v}}$ of pak-choi at $\mathrm{D} 49$, and the $\mathrm{HQ}_{\mathrm{v}}-\mathrm{TC}, \mathrm{HQ}_{\mathrm{v}}-\mathrm{CF}$, and $\mathrm{HQ}_{\mathrm{v}}-\mathrm{BF}$ was $20-89 \%$ in comparison with the CK. However, $B C^{\prime}$ s effect on the $H_{Q_{v}}$ of lettuce was contrary to that of pak-choi because the $\mathrm{HQ}_{\mathrm{v}}$ increased compared with $\mathrm{CK}$. The $\mathrm{HQ}_{\mathrm{v}}$ of lettuce and pak-choi used in this study was lower in comparison with water spinach grown in artificially Cd-spiked soils with a total concentration of $2.8-3.1 \mathrm{mg} / \mathrm{kg}$ [53]. According to the calculated results of $\mathrm{HQ}_{\mathrm{v}}-\mathrm{CF}$ and $\mathrm{HQ}_{\mathrm{v}}-\mathrm{BF}$, except for pak-choi grown in $\mathrm{CK}$, oral intake of these four leafy vegetables has a low risk even though the soil Cd concentration was 2 to 3 times beyond the control standard of farmland, i.e., $5 \mathrm{mg} / \mathrm{kg}$, based on the SGWPR Act of Taiwan.

\section{Conclusions}

Experimental results evidenced that the application of $\mathrm{BC}$ was able to increase the soil $\mathrm{pH}$ and decrease the accumulation of $\mathrm{Cd}$ in the roots and shoots of leafy vegetables used in this study. The $\mathrm{BCF}$ also decreased under BC treatment compared with control. However, BC's effect on the upward transfer of $\mathrm{Cd}$ from root to shoot was dependent on crop species. Because some of the accumulated $\mathrm{Cd}$ in the vegetables will leach out of tissues during cooking, using total concentration of $\mathrm{Cd}$ in the vegetables cannot actually reflect the real dose of $\mathrm{Cd}$ absorbed by the human body. Based on the $\mathrm{HQ}_{\mathrm{v}}$ calculation using the chemical form and bioaccessible fraction of $\mathrm{Cd}$ in the edible parts of blanched leafy vegetables, all of the vegetables grown in the study soil had low risk through oral intake, especially under BC treatment.

Author Contributions: Conceptualization and methodology, H.-Y.L.; sample analysis, K.-S.C. and C.-Y.P.; writing-original draft preparation, K.-S.C. and C.-Y.P.; writing-review and editing, H.-Y.L. All authors have read and agreed to the published version of the manuscript.

Funding: This research was funded by the Ministry of Science and Technology of the R.O.C. (Grant number MOST 108-2313-B-005-026) and by the Ministry of Education, Taiwan, R.O.C., under the Higher Education Sprout Project.

Acknowledgments: We would like to thank the students of the Soil Survey and Remediation Laboratory, Department of Soil and Environmental Sciences, National Chung Hsing University, for their assistance during the pot experiment and analysis.

Conflicts of Interest: The authors declare no conflicts of interest.

\section{References}

1. Hseu, Z.Y.; Su, S.W.; Lai, H.Y.; Guo, H.Y.; Chen, T.C.; Chen, Z.S. Remediation techniques and heavy metal uptake by different rice varieties in metal-contaminated soils of Taiwan: New aspects for food safety regulation and sustainable agriculture. Soil Sci. Plant Nutr. 2010, 56, 31-52. [CrossRef]

2. SGWPR Act (Soil and Groundwater Pollution Remediation Act). Available online: https://sgw.epa.gov.tw/en/ laws_policy/laws/458db6eb-5602-46b2-9471-745d58078aaf (accessed on 5 March 2020).

3. Di Toppi, L.S.; Gabbrielli, R. Response to cadmium in higher plants. Environ. Exp. Bot. 1999, 41, $105-130$. [CrossRef]

4. Chen, D.; Guo, H.; Li, R.; Li, L.; Pan, G.; Chang, A.; Joseph, S. Low uptake affinity cultivars with biochar to tackle Cd-tainted rice-A field study over four rice seasons in Hunan, China. Sci. Total Environ. 2016, 541, 1489-1498. [CrossRef]

5. Ali, H.; Khan, E.; Ilahi, I. Environmental chemistry and ecotoxicology of hazardous heavy metals: Environmental persistence, toxicity, and bioaccumulation. J. Chem. 2019, 2019, 1-14. [CrossRef]

6. Barraza, F.; Schreck, E.; Lévêque, T.; Uzu, G.; López, F.; Ruales, J.; Prunier, J.; Marquet, A.; Maurice, L. Cadmium bioaccumulation and gastric bioaccessibility in cacao: A field study in areas impacted by oil activities in Ecuador. Environ. Pollut. 2017, 229, 950-963. [CrossRef] [PubMed] 
7. Kovacevic, G.; Kastori, R.; Merkulov, L. Dry matter and leaf structure in young wheat plants as affected by cadmium, lead, and nickel. Biol. Plant. 1999, 42, 119-123. [CrossRef]

8. Liu, Y.T.; Chen, Z.S.; Hong, C.Y. Cadmium-induced physiological response and antioxidant enzyme changes in the novel cadmium accumulator, Tagetes patula. J. Hazard. Mater. 2011, 189, 724-731. [CrossRef]

9. Xu, D.Y.; Chen, Z.F.; Sun, K.; Yan, D.; Kang, M.J.; Zhao, Y. Effect of cadmium on the physiological parameters and the subcellular cadmium localization in the potato (Solanum tuberosum L.). Ecotox. Environ. Safe. 2013, 97, 147-153. [CrossRef]

10. Lasat, M.M.; Baker, A.J.M.; Kochian, L.V. Physiological characterization of root $\mathrm{Zn}^{2+}$ absorption and translocation to shoots in $\mathrm{Zn}$ hyperaccumulator and nonaccumulator species of Thlaspi. Plant Physiol. 1996, 112, 1715-1722. [CrossRef]

11. Lasat, M.M.; Fuhrmann, M.; Ebbs, S.D.; Cornish, J.E.; Kochian, L.V. Phytoremediation of a radiocesium-contaminated soil: Evaluation of cesium-137 bioaccumulation in the shoots of tree plant species. J. Environ. Qual. 1998, 7, 165-169. [CrossRef]

12. Küpper, H.; Zhao, F.J.; McGrath, S.P. Cellular compartmentation of zinc in leaves of the hyperaccumulator Thlaspi caerulescens. Plant Physiol. 1999, 119, 305-311. [CrossRef] [PubMed]

13. Ge, W.; Jiao, Y.Q.; Sun, B.L.; Qin, R.; Jiang, W.S.; Liu, D.H. Cadmium-mediated oxidative stress and ultrastructural changes in root cells of poplar cultivars. S. Afr. J. Bot. 2012, 83, 98-108. [CrossRef]

14. Haynes, R.J. Ion exchange properties of roots and ionic interactions within root apoplasm: Their role in ion accumulation by plants. Bot. Rev. 1980, 46, 75-99. [CrossRef]

15. Zhao, Y.F.; Wu, J.F.; Shang, D.R.; Ning, J.S.; Zhai, Y.X.; Shend, X.F.; Ding, H.Y. Subcellular distribution and chemical forms of cadmium in the edible seaweed, Porphyra yezoensis. Food Chem. 2015, 168, 48-54. [CrossRef] [PubMed]

16. Wu, F.B.; Dong, J.; Qian, Q.Q.; Zhang, G.P. Subcellular distribution and chemical form of Cd and Ca-Zn interaction in different barley genotypes. Chemosphere 2005, 60, 1437-1446. [CrossRef]

17. Su, Y.; Liu, J.L.; Lu, Z.W.; Wang, X.M.; Zhang, Z.; Shi, G.G. Effects of iron deficiency on subcellular distribution and chemical forms of cadmium in peanut roots in relation to its translocation. Environ. Exp. Bot. 2014, 97, 40-48. [CrossRef]

18. Fu, X.; Dou, C.; Chen, Y.; Chen, X.; Shi, J. Subcellular distribution and chemical forms of cadmium in Phytplacca americana L. J. Hazard. Mater. 2011, 186, 103-107. [CrossRef]

19. Wang, X.; Liu, Y.G.; Zeng, G.M.; Chai, L.Y.; Song, X.C.; Min, Z.Y.; Xiao, X. Subcellular distribution and chemical forms of cadmium in Bechmeria nivea (L.) Gaud. Environ. Exp. Bot. 2008, 62, 389-395. [CrossRef]

20. Qiu, Q.; Wang, Y.; Yang, Z.; Yuan, J. Effects of phosphorus supplied in soil on subcellular distribution and chemical forms in two Chinese flowering cabbage (Brassica parachinensis L.) cultivars differing in cadmium accumulation. Food Chem. Toxicol. 2011, 49, 2260-2267. [CrossRef]

21. Lai, H.Y. Subcellular distribution and chemical forms of cadmium in Impatiens walleriana in relation to its phytoextraction potential. Chemosphere 2015, 138, 370-376. [CrossRef]

22. Garau, G.; Castaldi, C.; Santona, L.; Deiana, P.; Melis, P. Influence of red mud, zeolite and lime on heavy metal immobilization, culturable heterotrophic microbial populations and enzyme activities in a contaminated soil. Geoderma 2007, 142, 47-57. [CrossRef]

23. Cao, X.; Dermatas, D.; Xu, X.; Shen, G. Immobilization of lead in shooting range soils by means of cement, quicklime, and phosphate amendments. Environ. Sci. Pollut. Res. 2008, 15, 120-127. [CrossRef] [PubMed]

24. Liu, N.; Jiang, Z.; Li, X.; Liu, H.; Li, N.; Wei, S. Mitigation of rice cadmium (Cd) accumulation by joint application of organic amendments and selenium (Se) in high-Cd-contaminated soils. Chemosphere 2020, 241, 125106. [CrossRef] [PubMed]

25. Shuman, L. Organic waste amendments effect on zinc fraction of two soils. J. Environ. Qual. 1999, 28, 1442-1447. [CrossRef]

26. Egene, C.E.; Van Poucke, R.; OK, Y.S.; Meers, E.; Tack, F.M.G. Impact of organic amendments (biochar, compost and peat) on $\mathrm{Cd}$ and $\mathrm{Zn}$ mobility and solubility in contaminated soil of the Campine region after three years. Sci. Total Environ. 2018, 626, 195-202. [CrossRef]

27. Ahmad, M.; Rajapaksha, A.U.; Lim, J.E.; Zhang, M.; Bolan, N.; Mohan, D.; Vithanage, M.; Lee, S.S.; Ok, Y.S. Biochar as a sorbent for contaminant management in soil and water: A review. Chemosphere 2014, 99, 19-33. [CrossRef] 
28. Moreno-Jiménez, E.; Esteban, E.; Carpena-Ruiz, R.O.; Lobo, M.C.; Rénalos, J.M. Phytostabilisation with Mediterranean shrubs and liming improved soil quality in a pot experiment with a pyrite mine soil. J. Hazard. Mater. 2012, 201-202, 52-59. [CrossRef]

29. Xu, C.; Chen, H.X.; Xiang, Q.; Zhu, H.H.; Wang, S.; Zhu, Q.H.; Huang, D.Y.; Zhang, Y.Z. Effect of peanut shell and wheat straw biochar on the availability of $\mathrm{Cd}$ and $\mathrm{Pb}$ in a soil-rice (Oryza sativa L.) system. Environ. Sci. Pollut. Res. 2017, 25, 1147-1156. [CrossRef]

30. Wang, Y.M.; Tang, D.D.; Zhang, X.H.; Uchimiya, M.; Yuan, X.Y.; Li, M.; Chen, Y.Z. Effects of soil amendments on cadmium transfer along the lettuce-snail food chain: Influence of chemical speciation. Sci. Total Environ. 2019, 649, 801-807. [CrossRef]

31. Zhang, X.Y.; Zhang, Y.M.; Liu, X.Y.; Zhang, C.Y.; Dong, S.D.; Liu, Q.; Deng, M. Cd uptake by Phytolacca americana L. promoted by cornstalk biochar amendments in Cd-contaminated soil. Int. J. Phytorem. 2019, 22, 251-258. [CrossRef]

32. Chen, Z.S.; Lee, D.Y. Evaluation of remediation techniques on two cadmium-polluted soils in Taiwan. In Remediation of Soils Contaminated with Metals; Iskander, I.K., Adriano, D.C., Eds.; Science Reviews: Northwood, UK, 1997; pp. 209-223.

33. Thomas, G.W. Soil pH and soil acidity. In Methods of Soil Analysis. Part. 3 Chemical Methods; Sparks, D.L., Page, A.L., Helmke, P.A., Loeppert, R.H., Soltanpour, P.N., Tabatabai, M.A., Johnston, C.T., Sumner, M.E., Eds.; SSSA Inc./ASA Inc.: Madison, WI, USA, 1996; pp. 475-490.

34. Rhoades, J.D. Salinity: Electrical conductivity and total dissolved solids. In Methods of Soil Analysis. Part 3. Chemical Methods; Sparks, D.L., Page, A.L., Helmke, P.A., Loeppert, R.H., Soltanpour, P.N., Tabatabai, M.A., Johnston, C.T., Sumner, M.E., Eds.; SSSA Inc./ASA Inc.: Madison, WI, USA, 1996; pp. 417-435.

35. Nelson, D.W.; Sommers, L.E. Total carbon, organic carbon, and organic matter. In Methods of Soil Analysis. Part 3. Chemical Methods; Sparks, D.L., Page, A.L., Helmke, P.A., Loeppert, R.H., Soltanpour, P.N., Tabatabai, M.A., Johnston, C.T., Sumner, M.E., Eds.; SSSA Inc./ASA Inc.: Madison, WI, USA, 1996; pp. 961-1010.

36. Sumners, M.E.; Miller, W.P. Cation exchange capacity and exchange coefficients. In Methods of Soil Analysis. Part 3. Chemical Methods; Sparks, D.L., Page, A.L., Helmke, P.A., Loeppert, R.H., Soltanpour, P.N., Tabatabai, M.A., Johnston, C.T., Sumner, M.E., Eds.; SSSA Inc./ASA Inc.: Madison, WI, USA, 1996; pp. 1201-1229.

37. Gee, G.W.; Bauder, J.W. Particle-size analysis. In Methods of Soil Analysis. Part 1. Physical and Mineralogical Method, 2nd ed.; Klute, A., Ed.; SSSA Inc./ASA Inc.: Madison, WI, USA, 1986; pp. 383-412.

38. EPA/Taiwan. Method Code No: NIEA S321.65B; Environmental Protection Administration of Taiwan ROC: Taipei, Taiwan, 2018.

39. Bremner, J.M. Nitrogen-Total. In Methods of Soil Analysis. Part 3. Chemical Methods; Sparks, D.L., Page, A.L., Helmke, P.A., Loeppert, R.H., Soltanpour, P.N., Tabatabai, M.A., Johnston, C.T., Sumner, M.E., Eds.; SSSA Inc./ASA Inc.: Madison, WI, USA, 1996; pp. 1085-1121.

40. Kuo, S. Phosphorus. In Methods of Soil Analysis. Part 3. Chemical Methods; Sparks, D.L., Page, A.L., Helmke, P.A., Loeppert, R.H., Soltanpour, P.N., Tabatabai, M.A., Johnston, C.T., Sumner, M.E., Eds.; SSSA Inc./ASA Inc.: Madison, WI, USA, 1996; pp. 869-919.

41. Helmke, P.A.; Sparks, D.L. Lithium, Sodium, Potassium, Rubidium, and Cesium. In Methods of Soil Analysis. Part 3. Chemical Methods; Sparks, D.L., Page, A.L., Helmke, P.A., Loeppert, R.H., Soltanpour, P.N., Tabatabai, M.A., Johnston, C.T., Sumner, M.E., Eds.; SSSA Inc./ASA Inc.: Madison, WI, USA, 1996; pp. 551-574.

42. De Medici, D.; Komínková, D.; Race, M.; Fabbricino, M.; Součková, L. Evaluation of the potential for caesium transfer from contaminated soil to the food chain as a consequence of uptake by edible vegetables. Ecotox. Environ. Safe 2019, 171, 558-563. [CrossRef] [PubMed]

43. Yu, T.H.; Hsieh, S.P.; Su, C.M.; Huang, F.J.; Hung, C.C.; Yiin, L.M. Analysis of Leafy Vegetable Nitrate Using a Modified Spectrometric Method. Int. J. Anal. Chem. 2018, 2018, 1-6. [CrossRef] [PubMed]

44. Baker, D.E.; Amacher, M.C. Nickel, copper, zinc, and cadmium. In Methods of Soil Analysis. Part 2. Chemical and Microbiological Properties, 2nd ed.; Page, A.L., Millers, R.H., Keeney, D.R., Eds.; SSSA Inc./ASA Inc.: Madison, WI, USA, 1982; pp. 323-336.

45. Mench, M.J.; Didier, V.L.; Loffler, M.; Gomez, A.; Masson, P. A mimicked in-situ remediation study of metal-contaminated soils with emphasis on cadmium and lead. J. Environ. Qual. 1994, 23, 58-63. [CrossRef]

46. Ure, A.M. Methods of analysis of heavy metals in soils. In Heavy Metals in Soils, 2nd ed.; Alloway, B.J., Ed.; Blackie Academic and Professional: London, UK, 1995; pp. 58-102. 
47. Lam, C.M.; Lai, H.Y. Effect of inoculation with arbuscular mycorrhizal fungi and blanching on the bioaccessibility of heavy metals in water spinach (Ipomoea aquatica Forsk.). Ecotox. Environ. Safe 2018, 162, 563-570. [CrossRef]

48. European Commission (EC). Commission Regulation (EU) No 420/2011 of 29 April 2011 amending Regulation (EC) No 1881/2006 setting maximum levels for certain contaminants in foodstuffs. Off. J. Eur. Union 2011, 11, 3-6.

49. Lai, H.Y.; Chen, B.C. The dynamic growth exhibition and accumulation of cadmium of pak choi grown in contaminated soils. Int. J. Environ. Res. Public Health 2013, 10, 5284-5298. [CrossRef]

50. Antoniadis, V.; Shaheen, S.M.; Boersch, J.; Frohne, T.; Laing, G.D.; Rinklebe, J. Bioavailability and risk assessment of potentially toxic elements in garden edible vegetables and soils around a highly contaminated former mining area in Germany. J. Environ. Manag. 2017, 186, 192-200. [CrossRef] [PubMed]

51. European Food Safety Authority. Scientific Opinion of the Panel on Contaminants in the Food Chain on a request from the European Commission of cadmium in food. ESFA J. 2009, 980, 1-139.

52. Kim, K.; Melough, M.M.; Vance, T.M.; Noh, H.; Koo, S.I.; Chun, O.K. Dietary cadmium intake and sources in the US. Nutrients 2019, 11, 2. [CrossRef]

53. Lam, C.M.; Chen, K.S.; Lai, H.Y. Chemical forms and health risk of cadmium in water spinach grown in contaminated soil with an increased level of phosphorus. Int. J. Environ. Res. Public Health 2019, 16, 3322. [CrossRef]

(C) 2020 by the authors. Licensee MDPI, Basel, Switzerland. This article is an open access article distributed under the terms and conditions of the Creative Commons Attribution (CC BY) license (http://creativecommons.org/licenses/by/4.0/). 